\title{
RISK MANAGEMENT RELATED TO IDENTIFYING WORK ACCIDENTS IN LOADING AND UNLOADING CONTAINER ACTIVITIES AT THE BERLIAN TERMINAL TANJUNG PERAK SURABAYA WITH THE HAZARD IDENTIFICATION RISK ASSESSMENT AND DETERMINING CONTROL (HIRADC) METHOD
}

\author{
Alfri Yoga Kurniawan \\ Faculty of Engineering \\ Civil Engineering Study Program \\ Narotama University Surabaya \\ alfriliebherr07@gmail.com \\ Fredy Kurniawan \\ Faculty of Engineering \\ Civil Engineering Study Program \\ Narotama University Surabaya \\ fredykurniawan@narotama.ac.id
}

\begin{abstract}
The Berlian Terminal is one of the container terminals located in the Port of Tanjung Perak Surabaya, managed by PT BJTI PORT. Container loading and unloading activities have a risk of work accidents. Work accidents can be prevented by applying Hazard Identification, Risk Assessment, and Determining Control (HIRADC). HIRADC aims to identify potential hazards in the workplace by linking workers, tasks, work equipment, and the work environment. This study aims to determine the application of HIRADC to reduce the risk of accidents. This type of research is descriptive research. The total sample of 52 workers, taken by the total sampling method. Data related to respondent characteristics such as worker productivity and the OHS Program on HIRADC were obtained by direct observation in the field and interviews with all workers. The results showed that workers who had high productivity were $(71.1 \%)$. Statistical tests using the ordinal regression test showed that there was an influence between the OHS Program on HIRADC and the Productivity of Work for Workers in Berlian Terminal $(0,000<0.05)$. The implementation of the OHS Program at the Berlian Terminal is good and needs to be maintained, if possible, it can be improved by increasing the competency of OHS Supervisors and OHS management following OHS regulations.
\end{abstract}

Keywords: Hiradc, Work productivity, OHS program,

\section{INTRODUCTION}

\section{Research Background}

Occupational safety and health (OHS) programs have become very important to consider, because OHS management is not only the responsibility of the company's HR department but also the responsibility of all parties in the company. Some of the benefits of implementing OHS management in the workplace are (1) increased efficiency and healthier workforce quality, (2) productivity increases due to reduced lost work days, (3) spending on medication and life insurance decreases, and (4) increasing company reputation.

The results of research conducted by Yuda Rifani (2018) in a case study of Prof. Road Access Entrance Road Construction project. DR. H. Hadari Nawawi with a target of 80 project workers showed that $87.25 \%$ of respondents stated that the application of OSH management was well implemented and that $80 \%$ of the workers agreed that the $\mathrm{OSH}$ culture at the project site had proceeded well. The test results using linear regression showed that OHS culture had a significant influence in influencing work productivity of workers. The results of this study are in line with research conducted by Zulfiana and 
Musyafa (2013) that the application of the OHS program in the work environment of PT. YTL East Java on Steam Turbine PLTU in Unit 5 Paiton Electricity Generation has a significant effect on increasing employee productivity. The better the application of the OHS program, the better the productivity of its employees, and vice versa. Through the implementation of a sustainable OHS culture, it is expected to reduce the level of work accidents and be able to increase employee morale. According to Ramli (2010) that workers who are guaranteed safety and health will work more productively so this will support success in the development of the company. Each workplace has potential and risks of danger to its workforce, one of which is a port service business entity. PT BJTI PORT is a subsidiary of PT Pelabuhan Indonesia III, which is a state-owned business entity as a port service provider that carries out activities as a terminal terminal operator, calculated since early January 2002 with a focus on cargo and container handling services in conventional terminals, where the company has implemented a OHS Management System. Many work activities are carried out outdoors, looking at environmental conditions and work processes that are very vulnerable and at high risk of workplace accidents, this PT BJTI company must be responsible for providing protection to its workers by implementing OHS culture in the workplace. The success of a company depends on the work productivity of its workers. Therefore, the study aims to analyze the effect of the OHS program on HIRADC on work productivity in workers at the Berlian Terminal.

\section{RESEARCH METHODS}

The design of this study was observational analytic with cross sectional study design. Namely a research design to study the dynamics of the correlation between risk factors, by means of an observation or data collection approach at a time. In this case the OHS program on HIRADC becomes an independent variable and work productivity as the dependent variable. The population in this study were all workers in the Berlian Terminal of 52 people divided into three shifts. The sample size was 52 people drawn by accidental sampling method. Data collection is divided into two, namely primary data and secondary data. Primary data were obtained by getting data / information directly from the workers at PT BJTI who were respondents during the interview or observations, while secondary data was obtained through the company management or library to support research. The data obtained were then analyzed using the SPSS program.

Characteristics of Respondents

RESULTS AND DISCUSSION

Table 1 Distribution of Individual Characteristics of Workers in Berlian Terminal

\begin{tabular}{|c|c|c|c|}
\hline Characteristics of Respondents & Category & $\%$ \\
\hline \multirow{3}{*}{ Level of education } & High school & 35 & 67.3 \\
\hline \multirow{4}{*}{ Position } & D3 & 6 & 11.5 \\
\cline { 2 - 4 } & S1 & 11 & 21.2 \\
\hline \multirow{6}{*}{} & Operator HMC/RTG/RS/HT & 37 & 71.2 \\
\cline { 2 - 4 } & Supervisor on Duty (SOD) & 4 & 7.7 \\
\cline { 2 - 4 } & Mechanical & 3 & 5.7 \\
\cline { 2 - 4 } & Foreman & 2 & 3.8 \\
\cline { 2 - 4 } & Paramedic & 1 & 1.9 \\
\cline { 2 - 4 } & Analyst Operational & 1 & 1.9 \\
\cline { 2 - 4 } & Manager on Duty (MOD) & 1 & 1.9 \\
\cline { 2 - 4 } & HSSE & 1 & 1.9 \\
\cline { 2 - 4 } & Tally & 1 & 1.9 \\
\cline { 2 - 4 } & Security & 1 & 1.9 \\
\hline \multirow{5}{*}{ Shift work } & $00.00-08.00$ & 18 & 34.6 \\
\hline & $08.00-16.00$ & 23 & 44.2 \\
\hline
\end{tabular}




\begin{tabular}{|c|c|c|c|}
\hline & $16.00-00.00$ & 11 & 21.26 \\
\hline \multirow{3}{*}{ Years of service } & $\geq 5$ Years & 32 & 61.5 \\
\cline { 2 - 4 } & $\leq 5$ Years & 20 & 38.5 \\
\hline \multirow{3}{*}{ Work productivity } & High Work Productivity & 37 & 71.1 \\
\cline { 2 - 4 } & Medium Work Productivity & 11 & 21.2 \\
\cline { 2 - 4 } & Low Work Productivity & 5 & 7.7 \\
\hline \multirow{3}{*}{ OHS Program (HIRADC) } & There and well socialized & 36 & 69.23 \\
\cline { 2 - 4 } & There is and rarely socialized & 15 & 28.85 \\
\cline { 2 - 4 } & There is and never socialized & 1 & 1.92 \\
\hline \multicolumn{2}{|c|}{ Amount } & 52 & 100.0 \\
\hline
\end{tabular}

Source: Primary Data, 2019

From the data in Table 1 shows the distribution of individual characteristics in loading and unloading workers at Berlian Terminal, out of 52 workers who were respondents in this study, most of the level of education was 35 people $(67.3 \%), 11$ people $(21, \mathrm{~S} 1) 1 \%$ ) the remaining 6 people (11.5\%) have D3 education with a work period of more than 5 years of 32 people $(61.5 \%)$ and the most dominant part is the lifting equipment operator (HMC / RTG / RS / HT) namely as many as 37 people (71.2\%). The OHS management system in the Berlian Terminal has been well implemented, so that the application of the OHS program in Berlian terminal has been felt very well by workers because 36 workers $(69.23 \%)$ are of the opinion that the OHS program has been well socialized to workers. Based on the results of the work productivity assessment carried out on employees at the Berlian Terminal, 37 people $(71.1 \%)$ had high work productivity.

\subsection{Effects of the OHS Program (HIRADC)}

Data Table 2 shows the effect test between the OHS program on HIRADC and work productivity at the Berlian Terminal. Of the 52 workers who were respondents in this research activity, 36 were of the opinion that the OHS program on HIRADC in Berlian terminal had been well socialized and 30 people $(83.3 \%)$ had high work productivity, 5 others had moderate work productivity $(14.0 \%)$ and the rest have low work productivity $(2.7 \%)$. Statistical test results using ordinal regression indicate that there is an effect of the OHS program on HIRADC on work productivity $(0,000<0.005)$ on employees at Berlian Terminal

Table 2 Effects of the OHS Program (HIRADC)

\begin{tabular}{|c|c|c|c|c|c|c|c|c|c|}
\hline \multirow{3}{*}{\multicolumn{2}{|c|}{ Independent Variable }} & \multicolumn{6}{|c|}{ Dependent Variable (Work Productivity) } & \multirow[t]{3}{*}{$\mathrm{N}$} & \multirow[t]{3}{*}{$\%$} \\
\hline & & \multicolumn{2}{|c|}{$\begin{array}{l}\text { High Work } \\
\text { Productivity }\end{array}$} & \multicolumn{2}{|c|}{$\begin{array}{c}\text { Medium } \\
\text { Work } \\
\text { Productivity }\end{array}$} & \multicolumn{2}{|c|}{$\begin{array}{c}\text { Low Work } \\
\text { Productivity }\end{array}$} & & \\
\hline & & $\mathrm{N}$ & $\%$ & $\mathrm{~N}$ & $\%$ & $\mathrm{~N}$ & $\%$ & & \\
\hline \multirow{3}{*}{$\begin{array}{l}\text { OHS } \\
\text { program } \\
\text { about } \\
\text { hiradc in } \\
\text { the } \\
\text { Company }\end{array}$} & $\begin{array}{l}\text { There and well } \\
\text { socialized }\end{array}$ & 30 & 83.3 & 5 & 14.0 & 1 & 2.7 & 36 & 100 \\
\hline & $\begin{array}{l}\text { There is and } \\
\text { rarely socialized }\end{array}$ & 7 & 46.7 & 5 & 33.3 & 3 & 20.0 & 15 & 100 \\
\hline & $\begin{array}{l}\text { There is and } \\
\text { never socialized }\end{array}$ & 0 & 0 & 1 & 100 & 0 & 0 & 1 & 100 \\
\hline \multicolumn{2}{|l|}{ Amount } & 37 & 71.1 & 11 & 21.2 & 5 & 7.7 & 52 & 100 \\
\hline \multicolumn{10}{|c|}{ Ordinal Regression Test $=0.000<0.005$} \\
\hline
\end{tabular}


Human resources with high levels of productivity are needed to achieve company goals and productivity is one of the main points for the company. Productivity is the main indicator for the progress of a company, so that productivity increases in all parts of the system.

Factors that influence work productivity include work in accordance with educational background, attractive wages, protection of health and well-being at work, a good environment and work environment, as well as career path and personal development. Each workplace has the potential and risk of harm to labor, one of which is a business entity that provides port services. PT BJTI is a subsidiary of PT Pelabuhan Indonesia III which is a state-owned enterprise as a port service provider that carries out activities as a port terminal operator starting from January 2002 with a focus on cargo and container handling services in conventional terminals, where the company The OSH management system has been implemented. The number of work accidents reaches more than 100 cases / year, when viewed in the business sector, the number of work accidents in the construction service sector is highest compared to other sectors. The Indonesian Ministry of Manpower (2011) noted that work accidents were still dominated by construction services (31.9\%), followed by the manufacturing industry sector (31.6\%) and transportation (9.3\%). The effort made to reduce the number of work accidents is by applying the OHS management system (SMK3), by implementing (SMK3) in a company, the hope is that the number of work accidents can be reduced through the OHS program. Occupational safety and health $(\mathrm{OHS})$ programs have become very important to consider, because OHS management is not only the responsibility of the company's HR department but also the responsibility of all parties in the company.

The HIRADC (Hazard Identification, Risk Assessment and Determining Control) hierarchy Program has been prepared with the following aspects in mind.

1. Hazard Potential Identification and Risk Assessment

Hazard identification is to answer the question of what potential hazards can occur or afflict organizations or companies and how they occur. Whereas Risk Assessment is an assessment process used to identify potential hazards that can occur.

\section{Risk control (Determining Control)}

The potential hazards can be controlled by determining a priority scale first which can then help in prioritizing which can then assist in the selection of risk control called the risk control hierarchy. Evaluation analysis of proposed improvements with Determining Control is carried out for all machines including: Elimination, Substitution, Engineering Control, Administration Control and the use of PPE (Personal Protective Equipment).

\section{The Effect of OHS Program on HIRADC on Work Productivity on Workers in Berlian Terminal}

Occupational health and safety (OHS) is an effort made to reduce the number of occupational accidents and occupational diseases. The purpose of applying OHS is as follows. (1) Protect workers from the right to safety in carrying out work for the welfare of life and increasing national production and productivity. (2) Ensuring the safety of everyone else who is at work. (3) Production sources are maintained and used safely and efficiently. Companies that run their business safely (safety business), usually pay close attention to employee health, this means the company considers employees to be one of the company's assets that must be protected. One of the efforts made is to implement a OHS management system (SMK3) in the company, because by applying OHS the company will develop a OHS program that hopes to increase worker productivity. The results of this study indicate that the OHS program that has been implemented at PT Berlian Jasa Terminal Indonesia has an influence on the work productivity of workers at the Berlian Terminal. This is because the application of the OHS program in PT BJTI is considered to be very good by workers, because the OHS program has been running routinely and the workers have benefited from the application of OHS in the workplace. Workers, especially heavy equipment operators are 
more careful and introspective when working, before entering the work area safety meetings are usually held to remind workers about the potential and risk of hazards that can occur while working.

The results of this study are in line with research conducted by Rahman (2014) which states that there is an increase in OHS culture through the implementation of the OHS program will affect the increase in work productivity of heavy equipment mechanics workers in South Kalimantan. In addition, this study is also in line with research conducted by Pangestu (2016) that the occupational safety and health (OHS) program and work discipline have a significant and partially significant effect on work productivity.

Someone's work productivity can be influenced by management in the workplace the relationship between labor and the leadership of the organization. Good company management is management that efficiently regulates the resources and work systems to achieve increased productivity. The company's leadership commitment to implement (SMK3) in his company is one of the efforts made to supervise employees to be more careful in working so as to reduce the incidence of workplace accidents and occupational diseases.

\section{Conclusions}

\section{CONCLUSIONS}

1. The hazards identified in the Berlian Terminal are 30 hazards including: Stevadoring activities there are 20 hazards, Haulage activities there are 10 hazards

2. Risk / hazard assessment in Berlian Terminal, namely risk / danger with a low level of risk / hazard of 10 hazards, a moderate level of risk / danger of 8 hazards, a risk / hazard with a high level of risk of 10 hazards and a very high level of risk / danger of a number of 2 danger

3. From interviews with workers at Berlian terminal related to work productivity shows that most workers have high work productivity.

4. There is an influence between the OHS program on Hazard Identification, Risk Assessment and Determining Control with work productivity in workers at Berlian terminal, because workers who have high work productivity are workers who assume that the OHS program at PT BJTI has been socialized with good to the workers

\section{Suggestions}

\section{For Management of PT. BJTI PORT}

Researcher's suggestion to the management of PT. BJTI PORT that is eliminating or reducing the hazards that have been identified at the Berlian Terminal, reducing the level of risk/danger at the berlian terminal, immediately acting in the control of the planned hazard by referring to the HIRADC results. Maintaining the OHS program that has been implemented, if possible, can be improved by increasing the competence of OHS supervisors and management in accordance with regulations, in addition it is necessary to supervise occupational safety and health devices, especially in areas that are rarely traversed by field supervisors.

\section{For Workers}

Workers are expected to be able to increase their compliance and awareness to be able to work carefully and comply with all regulations related to OHS in the workplace with or without supervision from the company HSSE. 


\section{REFERENCES}

[1] Afandi, Rahmad, dkk. 2014. Usulan Penanganan Identifikasi Bahaya Menggunakan Teknik Hazard Identification Risk Assessment and Determining Control (HIRADC) (Studi Kasus di PT. Komatsu Undercarriage Indonesia). Jurnal Online Teknik Industri Itenas, Bandung

[2] Australian Standard / New Zealand Standard 4360 : 1999. Risk Management Guidelines

[3] Candra, Lian. 2016. Analisis Potensi Kecelakaan Akibat Kerja Dengan Prosedur Hazard Identification, Risk Assesment, and Determiningcontrol (HIRADC) Di Pt Aneka Adhilogam Karya. Jurnal Fakultas Ilmu Kesehatan Universitas Muhammadiyah Surakarta

[4] Fahmi, Irham. 2010. Manajemen Risiko. Bandung: Alfabeta.

[5] Handoko, Jonathan C. dan Jani Rahardjo. 2017. Perancangan Hazard Identification, Risk Assessment, And Determining Control (HIRADC) Di Schneider Electric Cikarang. Jurnal Tirta Vol. 5, No. 2, Juli 2017

[6] ISO 31000 Risk Management," The Golden Standard, vol. 45, no. 5, 2012.

[7] Kasmir. 2014. Bank dan Lembaga Keuangan Lainnya. Edisi Revisi 2014. Jakarta: Raja Grafindo Persada.

[8] Kosasih, Engkos dan Soewedo Hananto. 2012. Manajemen Keuangan \& Akuntansi Perusahaan Pelayaran, Edisi Kedua. Jakarta : Rajawali Pers.

[9] Muhanafi, Muhammad Yulfa. 2015. Penerapan Hazard Identification, Risk Assesment And Determining Control (HIRADC) Dalam Upaya Mengurangi Kecelakaan Kerja di PT Wijaya Karya Beton Tbk Ppb Majalengka. Jurnal Universitas Muhammadiyah Surakarta

[10] OHSAS 18001:2007. Occupational Health and Safety Management System Guideline For The Implementation of OHSAS 18001.

[11] Pramana, Tony. (2011). Manajemen Risiko Bisnis. Jakarta : Sinar Ilmu.

[12] Ramli, Soehatman. 2010. Sistem Manajemen Keselamatan \& Kesehatan Kerja OHSAS 18001. Jakarta : Dian Rakyat

[13] Reese, C.D. 2009. Occupational Health and Safety Management: A Practical Approach. Edisi kedua. New York: CRC Press.

[14] Ridley, John. 2010. Ikhtisar Kesehatan \& Keselamatan Kerja Edisi Ketiga. Jakarta: Erlangga.

[15] Rifani, Yuda. 2018. Penerapan OHS Konstruksi Dengan Menggunakan Metode HIRARC Pada Pekerjaan Jalan Akses Masuk (Studi Kasus : JL. Prof. DR. H. Hadari Nawawi Kalimantan Barat). Jurnal Mahasiswa Teknik Sipil Universitas Tanjungpura

[16] Rumita, W.P dan Jantitya. 2014. Analisi Risiko Keselamatan Dan Kesehatan Kerja Dengan Menggunakan Pendekatan HIRARC (Studi Kasus PT. Cola Cola Bottling Indonesia unit Semarang). Jurnal Teknik Industri Kampus UNDIP Tembalang

[17] Septyani Prihatiningsih dan Tjipto Suwandi. 2014. Penerapan Metode HIRADC Sebagai Upaya Pencegahan Kecelakaan Kerja Pada Pekerja Mesin Rewinder NCR Carbonless Division PT. Pindo Deli Pulp and Paper Mills 2 Karawang. Jurnal Fakultas Kesehatan Masyarakat Universitas Airlangga Surabaya

[18] Sheddy, Nagara. 2008. Kesekretarisan. Jakarta: Departemen Pendidikan Nasional. 
[19] Standards Australia. 1999. AS/NZS 4360:1999. Risk Management, Standards Australia, Sydney,.

[20] Suardi, R. 2005. Sistem Manajemen Keselamatan Dan Kesehatan Kerja. Jakarta: PPM,

[21] Suma'mur. 2013. Higiene Perusahaan dan Kesehatan Kerja (HIPERKES). Jakarta: Sagung Seto

[22] Susilo, L. J. dan Kaho, V.R. 2014. Manajemen Risiko Berbasis ISO 31000 untuk Industri Non Perbankan. Jakarta: PPM. 